PLEASE NOTE! THIS IS SELF-ARCHIVED VERSION OF THE ORIGINAL ARTICLE

To cite this Article: H. Lajunen, M. Lehtinen, S. Silajärvi, P. Tani (2018) CO-CREATING AND CO-DEVELOPING EDUCATION IN A CHANGING OPERATIONAL ENVIRONMENT, INTED2018 Proceedings, pp. 3223-3231.

doi: $\underline{10.21125 / \text { inted.2018.0620 }}$

URL: https://library.iated.org/view/LAJUNEN2018COC 


\title{
CO-CREATING AND CO-DEVELOPING EDUCATION IN A CHANGING OPERATIONAL ENVIRONMENT
}

\author{
Hanna Lajunen, Mira Lehtinen, Sisko Silajärvi, Petri Tani \\ Laurea University of Applied Sciences (FINLAND)
}

\begin{abstract}
Finland is currently undergoing social welfare and healthcare reform and currently the law preparation is under way. This means that soon Finland will be going through a huge health, social services, and regional government reform. This reform will also change operational environment in both secondary vocational education and higher education.
\end{abstract}

At present, the local communities publicly fund Finland's health care system. The reform aims to change this funding to the bigger counties. The objective of the health, social services and regional government reform is to produce more efficient services and increase equality in healthcare.

The reason Finland is planning such a reform is the hard-economic situation it will face in the future. With ageing population, there will be a need for more individualized and equal services with fewer taxes to spend. The reform challenges everyone on the fields of healthcare and social services to think new ways to produce services.

In Laurea University of Applied Sciences the main challenge is to discuss deeply about the contents and the way of implementation of the degree programs and adapt them to suit for the new requirements of the changing operational environment. Strong integration of different lines of businesses and sectors is the reform's main theme. This requires new ways of thinking from the educators.

With three workshop sessions and different methods of co-creation and service design, Laurea UAS was able to create four focus points and a vision of the future. The vision, which was created in the workshops, will be a guideline for all decision making. Focus points are more pragmatic and guides the everyday life in the classrooms. Notable aspect of this project is that two of the three workshops were facilitated by Laurea UAS' Master degree students.

The aim of the first workshop was to create a common vision of how the education will be developed and renewed in Laurea UAS so that it can respond to social and health care changes in Finland. Laurea UAS aims to co-create health and social services for Uusimaa region with a human-centered approach. These health and social services will be diverse, human-centered, fluent, collaborative, preventative, transparent, equal, efficient, and enhancing.

In the second workshop concentrated to Laurea UAS' vision and the bigger picture. This workshop produced new vision for Laurea UAS' health and social services branch but also four new focus points. This vision will be launched in August 2017. After the launch, it will be implemented through various workshops.

The third workshop continued the work with more practical approach. In the beginning of the workshop the new vision was refined and after that the group created an action matrix for upcoming tasks. This matrix showed some light to actual tasks which must be done to meet the aim.

After the third workshop work continues according to the action matrix. The project group stays responsible for this project and its implementation and results. 


\section{INTEGRATING SERVICES WITH COST-EFFECTIVENESS}

Finland is currently undergoing a major reform of public services which aims to strengthen the sustainability of public finances and reduce the welfare and health inequalities of the population. In the health, social services and regional government reform, the responsibility for organizing social welfare and healthcare services is assigned from municipalities to new counties established in this reform. Social welfare and healthcare services are coordinated in the most comprehensive way as possible to increase cost efficiency and service performance [1,2] The reason Finland is planning such a reform is the hard-economic situation it will face in the future. With ageing population, there will be a need for more individualized and equal services with fewer taxes to spend. The reform challenges everyone on the fields of healthcare and social services to think new ways to produce services.

Today, 295 municipalities and 190 social and healthcare organizations in Finland are responsible for producing publicly funded social welfare and healthcare services. After the reform in 2020 the responsibility for organizing these services has gone to the 18 counties formed in the regional reform [3]. The National Institute for Health and Welfare (THL) estimates that the change from smaller organizations to bigger units can help to achieve more equal and better social and healthcare services. In the long term, the change can also help to meet the goal of reducing the inequalities in the welfare and healthcare. THL points out that some of the planned counties in Finland are already weaker because of the lack of resources and skills which may make it difficult to achieve the objectives [4] In Sweden the release of basic social welfare and healthcare services has been shown to have weakened regional equality somewhat, mainly in the case of elderly people living alone and single-parent families, but the overall impact is estimated to be minor. [5]

Current social welfare and healthcare services providers, the municipalities, have developed their services by moving their social welfare and healthcare services under the same roof. By this development municipalities hope to achieve advantages in the production of social welfare and healthcare services for chronically ill who use a lot of services. [6] Social welfare and healthcare services reform will be carried out by continuing this customer-focused service integration. The goal is to achieve fluent, customer-oriented, and multidisciplinary care chains, well-being personnel and functional information systems. The focus of social welfare and healthcare services is prevention and individuals' right and possibility to choose. In elderly care services, the emphasis is on home-based services and on strengthening the position of caregivers. The service productivity leap will be made through digitalization. Public and private services will be developed and reformed as user-oriented as possible. The use of digital services and health technology will be enhanced also in counseling services and in the work of caregivers. In this way, the reform will result in more common health and well-being with common funds. $[1,4]$

To succeed in this reform, counties need to have multidisciplinary skills and ability to concentrate to the details. Digitalization is central in the renewal of the procedures, in fixing the sustainability gap and in the new integrated social welfare and healthcare services. [3] THL emphasizes that besides the integration of horizontal and vertical social welfare and healthcare services, it is important to ensure the integration of services in relation to municipal services and the promotion of health and well-being. [7]

In addition to the integration of services, the social welfare and health care reform will seek 3 billion cost savings during the 2020s. Success in cost savings requires goal-oriented change management. Reform creates the conditions for change, but the realization of cost benefits requires both cost-effectiveness and cost-curbing. The central task of change management is to enable the development of professional practices and thus create new operating models. Technological development enables some of the development of productivity and the reduction of costs, but the need for special attention and new types of measures requires increased labor productivity. New types of models and working methods are needed for service production 
processes, whereby the benefits of large-scale production are also highlighted in service production when larger units organize them. [8]

\section{FREEDOM OF CHOICE RELEASES COMPETITION}

As for today, a customer has an opportunity to choose their health-care center once a year in their home municipality in Finland. Choice can be made between any municipal health-care center and privately funded health-care center in the municipality of residence. There are only 2 to $4 \%$ of the citizens of Finland who have made a choice. The number among those who use healthcare services is $8 \%$. The customers who have used their right to choose their health-care center are the ones who use these services more than average citizen and are slightly more unwell than an average health-care center customer. The reasons behind the choice are often linked with location, quality of the services and availability of appointments. [6]

A central part of social welfare and healthcare services reform is a legislation which allows citizens to choose the service provider they want. This service provider can be public service producer, private service provider or even a services provider which operates on voluntary sector. This freedom of choice will mainly concern every basic level services and if applicable special level services. Future counties must differentiate arranging and production of social welfare and healthcare services. The production of social welfare and healthcare services will be the duty of the counties' service institutions. These service institutions will also cooperate with other service providers in the county to coordinate the production of all services needed. [4]

In Europe, the freedom to choose is widely in use in the field of basic social welfare and healthcare services. For example, in Sweden and in the United Kingdom the freedom of choice is developed with betterment of the position and markets of the private services providers in mind. This same idea is behind of Finland's reform. Finland's structures differ from many others because most of working-age population doesn't use municipal health-care centers at all or uses them seldom. This is possible because of good occupational health care system. The selection of services is also very wide in Finnish health-care centers compared to other countries. [6]

Based on a survey, carried out on health-care centers' customers, they want to choose their place of care and the professionals caring them [6]. When this same survey was carried out on demographic level the freedom to choose didn't rise among the most important aspects of the social welfare and healthcare services reform. The most important aspects in this survey were proficiency and equality of availability of the services [9].

In the United Kingdom is noticed that increased competition has improved the quality of management and this has led to improved clinical results. Increased competition which affects to qualitative factors can also improve the quality of the care without increasing the costs. Freedom of choice is also found to narrow the socio-economic differences in the United Kingdom. [10]

\section{COMPLETE INTEGRATION OF SERVICES OR GENUINE FREEDOM OF CHOICE?}

There is very little research made on how to combine service integration with freedom of choice in the field of social welfare and healthcare services. From the aspect of social welfare and healthcare services reform the main question is how the freedom of choice and service integration is being emphasized in legislation and decision-making. Wide consolidation of services can be useful for a citizen who needs to use social welfare and healthcare services often. At the same time, it can be troublesome from the freedom of choice point of view because social welfare and health-care centers with wide selection of services cannot be numerous. This is a restrictive fact which has an effect to freedom of choice. [6]

While producing the services one must remember that professionals need to change and renew their operations models to respond to the demand of customer-centered services. New operations 
models need to support the production of new services. [6] Educational system has a major role in the creation of a new culture and operations models in the field of social welfare and healthcare services.

\section{SOCIAL WELFARE AND HEALTHCARE REFORM MODIFY THE CURRENT EDUCATION}

Different legislations regulate Finland's education system. In 2005 Finnish Government and Parliament have enacted a law of eligibility requirements of personnel working on the field of social welfare and healthcare services. These eligibility requirements show that social welfare and healthcare sector is societally significant. The aim of this legislation is to improve the customers right to good social welfare and treatments by demanding that personnel have the education and knowledge needed to work on this field. [11,12]

The law covers all operations on the field of social welfare and healthcare services regardless of the services producer. The law is written with the current educational system in mind. The degrees which fulfill the requirements and give students the knowledge and eligibility to work on the field of social welfare and healthcare are stated in the law [12].

Degrees stated in the eligibility law can be studied in universities and in polytechnics. Different degrees can be studied in universities than in polytechnics. Student in a university studies first the bachelor's degree and after that a master's degree. The combined extent of the bachelor's degree and master's degree in universities is 300 study credits. After this he/she is eligible to work in the field of social welfare and healthcare. This degree consists of theoretical studies and practical training. There are six universities which offer degrees on the field of social welfare and healthcare. After master's degree, it is possible to continue the studies with licentiate's degree and doctor's degree. There are also many specialization studies available after completing master's degree studies. [12]

In polytechnics, the degree studies consist of theoretical studies and practical training as in universities. The extent of the polytechnic degree is 210 study credits and it gives the student a bachelor's degree. If one wishes to study master's degree in a polytechnic it is possible. Master's degree extends to 90 study credits. There are 23 polytechnics in Finland which offer degree studies in the field of social welfare and healthcare. [12]

Development of the education on the field of social welfare and healthcare has already started by the Ministry of Education and Culture. Personnel's skills are a key to succeed in social welfare and healthcare reform and to ensure the quality and effectiveness of the system. According to Minister of Education and Culture Sanni Grahn-Laasonen, the suitability for the field must be ensured in the student selection processes. To ensure the suitability a reform has been started which aims to develop tools for better assessment of the candidates who apply a degree place in the field concerned. Professionals do demanding and valuable work and it is crucial for the patient safety to be sure the candidates are suitable and motivated for social welfare and healthcare services work by their medical condition and functional abilities. The legislation acts are called SORA-acts which regulate the eligibility requirements for suitable candidates. These acts are enacted to guarantee the safety of the patients and customers. Changes to these acts have been discussed already in the spring of 2017. [13]

Key points to the social welfare and healthcare reform are service integration, customer-centered services, and freedom of choice. These points will change the services, division of labor and competence needs. It is critical that the competence of the professionals is noticed and it is utilized as well as possible. In addition to this Grahn-Laasonen emphasizes that self-development and flexible education is in an important role and both must be made possible. [13]

Service integration, one of the key points in the reform of social welfare and healthcare services, consists of organizing the services, flow of information, service chains and productional integration. 
By integrating all this service chains and packaged services should be emerged. In other words, the aim is to create customer-centered service integration where customer-centered approach can be seen as listening the customers when the need for services is evaluated, how the services are matched to the customers need and how the services are arranged and executed to the citizens. To achieve this aim changes to status quo must be made. Every operator on the field of social welfare and healthcare services must have common knowledge what other operators do and how the responsibility is distributed. The implementation of service chains and packaged services must be agreed in a way which makes multi-professional work and functions possible. Developing and reforming of education is one possible solution to these challenges. If education is a solution the educators must pay attention to what kind of professionals graduate from schools. These new professionals must reach for homogenous and customer-centered services. [14]

The role of digitalization in the reform of social welfare and healthcare services is significant for the customers' and professionals' points of views. Digitalization is a tool to save time when the customer doesn't need to travel to on the spot to take care of matters. The idea is that there would be a dialogical connection with a doctor or social worker in virtual environment. Digitalization offers also good tools for data transfer between different service providers which is one of the key points in this reform. [15]

Seen from the worldwide level, Finland is one of the top countries what comes to data management in the field of social welfare and healthcare services. For example, KANTA-services and digitalization of occupational safety surveillance have been successes. Digitalization can change the world continually and there are new services developed every day. Artificial intelligence and robotics are going to enable many digital social welfare and healthcare services as soon as in 2025. The population in Finland is aging and the expected lifetime is getting longer which increases the need for supportive services. There are also whole new customer groups using the social welfare and healthcare services with different needs when immigration increases. The customers of social welfare and healthcare services are changing and so should the services do too. New generations keep digitalization as a norm not as an additional service. Expectations of public services are great and justification for publicly funded services must be argued well. The social welfare and healthcare services must be offered to the customers with smaller financial resources because the public debt has grown too large. Citizens demand cost-efficiency, productivity, and effectivity from the services. Digitalization is a problem solver to these challenges if it is exploited correctly. [16].

Digitalization gives the social welfare and healthcare professionals a possibility to use data systems which support different processes. This possibility is written as one of the aims of the ongoing reform. New data systems bring new skill requirements to professionals already working on the field. Training courses will be held to educate the professionals to use new systems on their workplaces. When new professionals graduate it is important that they already possess the needed skills, and have the competence to work with new data systems. Therefore, study programs of different degrees must be changed. Study programs need to include more data management, data protection and security and use of created data systems. [17]

High competence level will be required from professionals working with social welfare and healthcare services and they must be granted with a possibility to develop themselves. Educational system needs to ensure that this possibility is conceivable. On nationwide level, the Ministry of Education and Culture is responsible that the educational system can answer to the needs of the Finnish society. At this point the Ministry sees that greatest challenges are competences relating to counseling, guidance, and cost-consciousness. Service counselling should be considered during the studies when competence in cost-consciousness and health economics is important within managerial personnel. Various projects are underway concerning competences but these projects lack a nationwide coordination on the educational level. High-level steering group will start cooperation with Ministry of Social Affairs and Health to recognize all needs for reform in the educational system. [13] 


\section{CO-CREATIVE WORKSHOPS IN LAUREA UNIVERSITY OF APPLIED SCIENCES}

While legislation is discussed in Finnish Parliament and Government concerning the coming social welfare and healthcare services reform, Laurea University of Applied Sciences wants to be in the heart of the reform. Their goal is to create best social welfare and healthcare services to Uusimaa region with co-creational approach. To reach this goal Laurea UAS needed to rethink their visions, procedures, and ways to work and teach. Only this way they could educate professionals who have the needed competence on the field of social welfare and healthcare after the reform is made.

Laurea SOTE 2020-project was launched to make the necessary reforms. The project group consisted of principals, headteachers and directors of Laurea UAS. Same project group is still responsible for implementing the changes within Laurea UAS's organization.

Because the success of social welfare and healthcare reform lays on the competences of the professionals working on the field, education system needs to change [13]. In Laurea UAS the changes were made with service design tools and co-creational techniques.

Key elements of the social welfare and healthcare services reform are to create and develop customer-centered services, which are widely integrated and freely selectable to the customer [13]. When we consider some of service designs principals and we compare them to the key elements of the reform similarities can be found. Service design has two major benefits when working with development projects. It is user-centered and co-creative. Development projects made with service design approach are sure to take every stakeholder along in the processes and keep the focus on the customer [18]. Service design methods were a natural choice when planning the Laurea SOTE 2020 -project.

The project consisted of 3 workshops. In these workshops, the project group co-created a new vision for Laurea UAS to follow during the social welfare and healthcare services reform. Workshops also produced simple action plan to follow while implementing the new vision in the organization.

Two of the workshops (workshops 2 and 3) were planned and facilitated by master's degree students of Laurea UAS. The first workshop which was held to launch the Laurea SOTE 2020 project was planned and facilitated by a staff member. Every workshop was planned and facilitated with co-creation and service design in mind and various tools were used to get the best possible vision for Laurea UAS in the changing operational landscape.

The first workshop of Laurea SOTE 2020 -project started with a discussion about the objective of the project. In that workshop, it was agreed that the objective is to have an impact on the ongoing reform with co-creational methods and through this to create the best social welfare and healthcare services to Uusimaa region.

The project group needed to clarify themselves what 'the best social welfare and healthcare services' means. When this information was gathered with post-it papers the group continued the work with discussion about the current situation of Laurea UAS mirroring it to the reform. The current situation was considered with four aspects: what could be done to reach the goal, matters that slow down or even prevent the project of going forward, what matters have a positive impact on the project and who are the other stakeholders and partners needed to achieve the goal.

As the result of the first workshop the project group noticed that there is a need for a lot of renewals in the curriculums, their contents and how the courses are executed. To be able to do these renewals there must be co-operation between different fields of studies. 
Information which was gathered in the first workshop was used as a starting point in the next one. After the workshop, it was clear to all participants that the social welfare and healthcare services reform challenges all players in the educational system to develop their procedures.

The aim of the second workshop was to produce a new vision for Laurea UAS to follow during and after the reform. This aim was set at the end of the first workshop to be able to continue with the development project.

The work started with a brief reminder of what had been discussed in the first workshop to help the participants to focus again on the subject. After the reminder, an idea generating tool was used to get more ideas to base the possible visions on. The idea generating tools are used by service designers to structure and inspire the group [18]. This was the reason the second workshop started with reminder and idea generating tool, called me-we-us. Me-we-us tool allows everyone to think first to themselves and activates the whole group equally. After the first step, the written ideas are shared first with one person and then in a larger group and lastly to the whole group or participants. [19]

Ideas written on post-it papers were evaluated in small groups as the next step of the workshop. To do the evaluation group used intuition assessment tool. This tool functions as an evaluative tool when participants discuss in smaller groups about the ideas they have gathered and organize them hierarchically [20]. After the evaluation, small groups were asked to visualize the new vision of Laurea UAS with the help of their evaluated ideas and to present them to the whole group.

This was done to get the best possible vision for Laurea UAS and to get every voice heard in the process. The project group worked their way from individual ideas and opinions to a consensus of the whole group. The group voted for the best vision and it was then evaluated and developed further.

The vision the group chose was evaluated with an open discussion and value-clock tool. This value-clock tool helped the group to evaluate the most important aspects of the chosen vision and make decisions. The aspects or values of the matter at hand are written on the edges of a circle. After this, arrows are drawn from each value either away or towards it according to its relation to the other value. The most important value is the one which has most of the arrows pointing at it. [21]

At this point, where the vision was visualized, explained, and evaluated, it was easy to see the benefits of a co-creational approach to the matter. The whole group seemed satisfied with the outcome and they all could stand behind their work no matter what.

The second workshop intentionally kept the discussion on the intangible level. There weren't any discussions about how to implement the changes needed or what actions should be done next. This decision needed to be done because the objective of the second workshop was to create the vision for Laurea UAS to build the practical action on.

In the third and last workshop, the project group worked with more hands-on attitude. The aim of this workshop was to create action plan to help in the implementation process of the new vision.

Same pattern was used in the third workshop as in the second one. Workshop started with a reminder or what had been done already. The new vision was evaluated again with fresh eyes and some adjustments were made to it. This helped the project group to immerse themselves again to the subject and let them continue the work more easily.

Planning of the action plan started with backcasting method to get some insight to what processes doesn't need to change and what processes does to implement the new vision. Backcasting was 
possible to use with this project because the vision of the future was created in the second workshop.

Backasting tool is basically a tool where the vision of the future is the starting point and the work moves backwards on the imagined timeline to present situation. This tool helps to see what practical changes must be made to future to be as visioned. Different solutions can be evaluated and discussed with it. [22]

Backcasting tool gave good results which were easy to transfer to simplified action plan. The project group co-created the action plan in the workshops and if Laurea UAS follows this action plan, the goals in the vision will be achieved.

The benefits of co-creational workshops were easy to see when facilitating the workshop and the work in them. Especially the benefits were visible in the third workshop where the action plan seemed to form with no effort at all. Co-creational approach helped the project group in decision making and after two workshops the new vision was so clear to everyone they naturally knew what actions were needed to implement it in the organization.

\section{CONCLUSIONS}

The health, social services and regional government reform in Finland will change the operational landscape on the field of healthcare and social services. The reform has a major impact also to education, especially in Universities which are mainly responsible of educating professionals to this field. The reform is planned to be ready in the beginning of 2020 and after that it will be implemented in Finland. If the reform will be implemented as it is planned, future professionals in the field of healthcare and social services will need different skills than today. Problems which need to be tackled are multidisciplinary co-operation, data transfers and cost-efficiency.

Anu Vehviläinen, Minister of Municipal Affairs and Reform, underlines a few points behind the success of the reform: management of multisectoral management, knowledge of details, solutionoriented approach and modernization of services and administration by utilizing digitality and interaction. In addition, change leadership has named the core issue of success. [3, 8] It is important for educational institutions to be aware of these factors by training future experts already today. The need for change applies to all levels of social and health education. Knowledge of change leadership is already needed when preparing for change. Institutions should follow changes in their operational environment and be able to react agile and flexible.

Changing operational landscape and planned new services need new ways of thinking. When digitalization and new business models emerge in the field of healthcare and social services it creates a challenge to the healthcare and social services professionals. New skills must be learned and whole different ways of thinking needs to be adopted. These new emerging workforce requirements challenge the educational system to adapt its procedures and curriculums. The Cope project is a cross-sectoral cooperation project aimed at investigating the change in social and health care and its impact on work, skills and competence development. In the project there are THL, Aalto University, Laurea UAS, Academy of Finland and University of Eastern Finland. [23] The Cope project provides important information on the development of vocational and continuing training in social and health care for the working life and educational institutions. If the education of healthcare and social services professionals doesn't change the nationwide reform cannot happen.

Success needs overhauled operating practices which may require new expertise and even create totally new occupations. Already known substantial changes are identified for instance service integration, digitalisation, increased importance of customer guidance and changes in division of duties between professional groups. [25] Nurses restricted right to prescribe medicines and guiding clients to a physiotherapist instead of a physician are already existing examples of this kind of changes. The challenge to educational institutes is to predict how these upcoming changes 
affect expertise needs, meaning both the competence needs of current professionals and professional now and tomorrow in training, and create educational programs that respond to the challenges of change.

Our case example Laurea University of Applied sciences has renewed their Master's degree programs to answer already to these changes. It concentrates on change leadership and development during healthcare and social services reform. The training is implemented in the context of the COPE research project, integrating the project results into action. The program aims to produce professionals who can work as specialists and experts of development during the reform and after it. [24] 


\section{REFERENCES:}

1] Finnish Government. 2015. Ratkaisujen Suomi. Neuvottelutulos strategisesti hallitusohjelmasta. [Solutions for Finland The agreement on the Strategic Government Program]. 27.5.2015. Available from:

http://valtioneuvosto.fi/documents/10184/1427398/Hallitusohjelma 27052015.pdf/75d94d8d-15c9-405a-8a9beca4987b635e [in Finnish]

2] Finnish Government. 2017. Ratkaisujen Suomi: Puolivälin tarkistus. Hallituksen toimintasuunnitelma vuosille 20172019. [Solutions for Finland: Checking half-way. Government Action Plan for 2017-2019.] Government Publication Series 5/2017. Available from: http://vnk.fi/documents/10616/4610410/Toimintasuunnitelma+H 5 2017+280417.pdf [in Finnish]

3] Vehviläinen, A. 2017. Maakuntauudistus - missä mennään? [Regional Reform - where do we go?] Presentation 6.9.2017. The Council of State. Available from: http://valtioneuvosto.fi/documents/10623/3779937/Maakuntauudistus++missä+mennään+6.9.2017.pdf/6b23958a-d559-46fa-a404-73624e136adb [in Finnish]

4] THL. National institute for health and welfare. 2016. Sosiaali- ja terveydenhuollon järjestämislakiluonnoksen vaikutusten ennakkoarviointi. [Preliminary assessment of the impact of the Draft Law on Social Welfare and Health Care.] Report 12/2016. Available from: http://www.julkari.fi/bitstream/handle/10024/130798/Rap2016 012.pdf?sequence=1_[in Finnish]

5] Isaksson, D. Blomqvist, P. Winblad, U. 2016. Free establishment of primary health care providers: effects on geographical equity. BMC Health Services Research (2016) 16:28. Available from: https://www.ncbi.nlm.nih.gov/pmc/articles/PMC4724405/pdf/12913 2016 Article 1259.pdf

6] Sinervo, T. Tynkkynen, L. 2017. Valinnanvapaus ja sote-uudistus - mitä aikaisemmasta tutkimuksesta voidaan oppia? [Freedom of choice and social and health care reform - what can be learned from earlier research?] Talous ja yhteiskunta [Economy and Society.] 1/2017: 56-62. Available from: http://www.labour.fi/ty/tylehti/ty/ty12017/ty12017pdf/ty12017SinervoTynkkynen.pdf [in Finnish]

7] Eskola, J. Pekurinen, M. 2017. Lausunto luonnoksesta laiksi asiakkaan valinnanvapaudesta sosiaali- ja terveydenhuollossa. [Opinion on draft law on customer choice in social and health care.] National institute for health and welfare. Available from:

https://www.thl.fi/documents/10531/3135381/Lausunto+218.Luonnos+asiakkaan+valinnanvapaudesta+sosiaali+ ja+terveydenhuollossa korjattu+versio.pdf/8f7b02c3-637e-48d5-8e5d-4c3f69d25af6 [in Finnish]

8] Finnish Ministry of Social Affairs and Health. Finnish Ministry of Finance. 2015. Sote-uudistuksen säästömekanismit. [Saving mechanisms for social and health care reform. ] Preliminary official clearance. 4.11.2015. Available from: http://vnk.fi/documents/10616/1865308/Arvio+sote-uudistuksen+säästöistä+ja+säästömekanismeista.pdf/c5c537127b8c-4bae-aa62-3d8953f73d3a [in Finnish]

9] Aalto, A. Manderbacka, K. Muuri, A. Karvonen, S. Junnila, M. Pekurinen, M. 2016. Mitä väestö ajattelee sosiaali- ja terveyspalveluiden uudistamisesta? [What does the population think about reforming social and health care services?] Summary of the study 4. March 2016. National institute for health and welfare. Available from: https://www.julkari.fi/bitstream/handle/10024/130233/TUTI2016 4 Mitä\%20väestö\%20ajattelee WEB.pdf?sequence=1 [in Finnish]

10] Whellams, A. 2016. Valinnanvapaus Englannin sosiaali- ja terveydenhuollossa. [Discretion in English Social and Health Care.] Work paper 2/2016. National institute for health and welfare. Available from: http://www.julkari.fi/bitstream/handle/10024/129795/URN ISBN 978-952-302-605-6.pdf?sequence=1_[in Finnish]

11] Finnish Ministry of Social Affairs and Health. 2007. Sosiaalihuollon ammatillisen henkilöstön kelpoisuusvaatimukset valtio-, kunta- ja yksityissektorilla. [Eligibility criteria for professional social welfare staff in the state, municipal and private sector.] Helsinki. Publications of the Ministry of Social Affairs and Health 2007:18. [in Finnish]

12] Talentia 2015. Sosiaalialan koulutukset ja kelpoisuudet. [Education and requirements on social welfare and healthcare professionals] . Pamphlet. Available from: http://www.talentia.fi/files/64/Kelpoisuusesite.pdf [in Finnish]

13] Finnish Ministry of Education and Culture. 2017. Sote-koulutuksen uudistaminen käynnistyy. [Renewal of social and health education is under way.] Available from. http://minedu.fi/artikkeli/-/asset publisher/sote-koulutuksen-uudistaminenkaynnistyy [in Finnish] 
14] Koivisto, J., Pohjola, P., Lyytikäinen, M., Liukko,E. Luoto, E. 2016. Ratkaisuja palveluiden yhteensovittamiseen. Innokylän innovaatiokatsaus. [Solutions for matching service. Innokylä innovation review.] Helsinki: National institute for health and welfare. [in Finnish]

15] Finnish Ministry of Social Affairs and Health. Finnish Ministry of Finance. Health, social services and regional government reform. Available from: http://alueuudistus.fi/en/frontpage

16] Finnish Ministry of Social Affairs and Health. Digitalisaatio terveyden ja hyvinvoinnin tukena. [Digitalization to support health and wellbeing. Social Affairs Ministry's Digitalisation Guidelines 2025.]Sosiaali- terveysministeriön digitalisaatiolinjaukset 2025. [Digitalization to support health and wellbeing. Social Affairs Ministry's Digitalisation Guidelines 2025.] Helsinki. Publications of the Ministry of Social Affairs and Health 2016:5.

17] Hyppönen, H., Aalto, A-M., Doupi, P., Hämäläinen, P., Kangas, M., Keränen, N., Kärki, J., Lääveri, T., Reponen, J. \& Ryhänen, M. 2016. Sosiaali- ja terveydenhuollon digitalisaatio. Seurantamittarit ja tuloksia Sote-tieto hyötykäyttöön strategian näkökulmasta. [Social and health care digitalisation. Monitoring Instruments and results for Sote data utilization - strategical point of view.] Helsinki: National institute for health and welfare. [in Finnish]

18] Schneider, J. \& Stickdorn, M. 2012, This is Service Design Thinking: Basics - Tools - Cases, BIS Publishers

19] Lehtola, J. Fasilitointi luo uutta. [Facilitation creates new.] Team Academy. Essay Bank. Referred 26.9.2017 http://esseepankki.tiimiakatemia.fi/fasilitointi-Iuo-uutta-3/ [in Finnish]

20] Tschimmel, K., Santos, J., Loyens, D., Jachinto, A., Monteiro, R. \& Valenca, M. 2015. Research Report D-Think.

21] Play \& Learn. 2012. Oppimisen arvokello. [The value clock of learning.] Available from: https://oppimisentaidot.wordpress.com/2012/02/13/oppimisen-arvokello/

22] Joint Research Center, European Comission. Online Foresight Guide. Backcasting. Available from: http://forlearn.jrc.ec.europa.eu/guide/4 methodology/meth backcasting.htm

23] Cope - Competent workforce for the future. https://www.stncope.fi/en/

24] Laurea UAS. 2017. SOTE-muutos keskiössä Laurean uudessa YAMK-koulutuksessa [Social and health care change at the core of Laurea's new master's degree program training] Available from:

https://www.laurea.fi/tiedotteet/Sivut/SOTE-muutos-keskiössä-Laurean-uudessa-YAMK-koulutuksessa.aspx _[in Finnish]

25] COPE. The Changing Working Life. https://www.stncope.fi/en/themes/the-changing-working-life/ 